ISSN 1027-5495. Functional Materials, 25, No.1 (2018), p. 93-99

doi:https://doi.org/10.15407/fm25.01.93

(C) 2018 - STC “Institute for Single Crystals"

\title{
Structure, crystallization and thermal behavior of fluorinated ethylene propylene (FEP) based plastics composites
}

\author{
Chen Jian-bing, Li Zhun-zhun, Xu Nan
}

\author{
School of Chemistry and Materials Engineering, Chizhou University, \\ Chizhou, Anhui, 247000, P.R. China
}

Received December 5, 2017

The FEP based binary and ternary plastics composites were prepared by melt blending. The microstructure, crystallization behavior and thermal degradation behavior of FEP/PEEK, FEP/ PEI and FEP/PEEK/PEI composites were investigated by FT-IR, SEM, DSC, XRD and TGA. The FT-IR, SEM and DSC results shows that the FEP/PEEK, FEP/PEI and FEP/PEEK/PEI composites were presented thermodynamics incompatible. The degree of crystallinity of FEP was decreased as PEEK or with PEI simultaneously were added to FEP matrix, while the degree of crystallinity of FEP increases first then decreases as PEI was added to FEP matrix. The TGA results shows that the thermal stability of FEP/PEEK composites enhance with PEEK content increases when the PEEK content is under 25\%, then decreased when the PEEK content is over $25 \%$, the thermal stability of FEP/PEI and FEP/PEEK/PEI composites decreased with PEI or PEEK added to the FEP matrix.

Keywords: FEP, PEEK, PEI, microstructure, crystallization behavior, thermal degradation

Бинарные и тройные пластиковые композиты на основе фрторированного этиленпропилена (FEP) были приготовлены путем смешивания в расплаве. Микроструктура, поведение кристаллизации и поведение тепловой деградации композитов FEP / PEEK, FEP / PEI и FEP / PEEK / PEI были исследованы с помощью FT-IR, SEM, DSC, XRD и TGA методов. Результаты показывают, что композиты FEP / PEEK, FEP / PEI и FEP / PEEK / PEI являются термодинамически несовместимыми. Степень кристалличности FEP уменьшалась, поскольку PEEK или PEI одновременно добавлялись к матрице FEP, тогда как степень кристалличности FEP сначала возрастала, а затем уменьшалась по мере добавления PEI к матрице FEP. Показано, что термическая стабильность композитов FEP / PEEK увеличивается с увеличением содержания PEEK, когда содержание PEEK составляет менее 25\%, а затем уменьшается, когда содержание PEEK превышает 25\%. Термическая стабильность FEP / PEI и FEP / PEEK/ композиты PEI уменьшается с добавлением РЕI или PEEK к матрице FEP.

Структура, кристалізація та термічні властивості пластмасових композитів на основі фторованих етіленпропілена (FEP). Chen Jian-bing, Li Zhun-zhun, Xu Nan. Бінарні і потрійні пластикові композити на основі фрторованих етіленпропілена (FEP) були приготовлені шляхом змішування в розплаві. Мікроструктуру, поведінку кристалізації і поведінку теплової деградації композитів FEP / PEEK, FEP / PEI і FEP / PEEK / PEI досліджено за допомогою FT-IR, SEM, DSC, XRD і TGA методів. Результати показують, що композити FEP / PEEK, FEP / PEI і FEP / PEEK / PEI є термодинамічно несумісними. Ступінь кристалічності FEP зменшувалася, оскільки PEEK або PEI одночасно додавалися до матриці FEP, тоді як ступінь кристалічності FEP спочатку зростала, а потім зменшувалася у міру додавання PEI до матриці FEP. Показано, що термічна стабільність композитів FEP / РEЕK збільшуеться зі збільшенням вмісту РЕEК, коли вміст РЕEК становить менше 25\%, а потім зменшуеться, коли вміст PEEK перевищуе 25\% . Термічна стабільність FEP / PEI і FEP / PEEK / композити PEI зменшуеться. Термічна стабільність FEP / PEI і FEP / PEEK / композити PEI зменшуеться з додаванням PEI або PEEK до матриці FEP. 


\section{Introduction}

(FEP) can be consider as modified polytetrafluoroethylene (PTFE), which is a copolymer of tetrafluoroethylene and hexafuoropropylene via free-radical polymerization. FEP is a kind of crystalline polymer, with similar in composition to the PTFE. FEP share the excellent properties of PTFE such as low friction, nonreactivity, corrosion resistance, low dielectric constant, uninflammable and excellent mechanical properties. Compared with PTFE, FEP have better processing property, because FEP having a melting point of $250 \sim 270{ }^{\circ} \mathrm{C}$, around $40{ }^{\circ} \mathrm{C}$ lower than Perluoroalkoxy polymer resin (PFA), and lower than PTFE.[1-2] FEP have widely used for wiring due to the properties of low dielectric constant and uninflammable.[3] In addition, because of the chemical composure and chemical fuels resistance in extreme temperatures, flexibility and optical transparency, FEP can be used as "release films" in manufacturing high-quality composites parts, and used for the application of plastic labware and medical apparatus and instruments. [4] However, the processing properties of FEP are better than some engineering plastics, but the tensile strength, creep resistance and abrasive resistance are reverse, which restricts its further application.

In order to extending the application fields of FEP, many researchers has been studied the modification of FEP with other polymers such as polypropylene (PP), Polyimide (PI), PTFE and polystyrene (PS). However, because of the chemical inertness of FEP, the repeated FEP based composites were prepared by radiation grafting method[5-7] and spray method. Liang $\mathrm{J} \mathrm{Z}$ et al[8] prepared the FEP/PP composites by melt extrusion molding, the melt shear behavior of PP, FEP and FEP/PP were investigated by Bohlin higher rheometer. The results showed that the melt shear viscosity of $\mathrm{PP}$ and FEP/PP composites conforms with the Arrhenius equation, FEP and FEP/PP composites presented obvious shear thinning with shear rate increases, the zero-shear viscosity of FEP/PP composites was enhanced with the weight fraction of $\mathrm{PP}$ increases. Zhao $\mathrm{H}$ et al[9] investigated the tribological properties od PI/ FEP self-lubricating composites with dry sliding, water-lubricated and oil-lubricated conditions. The results showed that the friction coefficients of PI/FEP composites under water lubrication were lower than under dry sliding, the wear rates were higher than under dry sliding. There exists lowest friction coefficients and wear rates under oil-lubricated condition. Wang $\mathrm{H}$ et al[10] repeated that the polyphenylene sulfide (PPS)/FEP/polyetheretherketone
(PEEK)/polydimethylsiloxane (PMDS) composite coating with excellent self-cleaning, bending/heat/wear-resistance and heating-stability properties have been prepared by spray method. The research results showed that the contact angles of water, glycerine, ethylene glycol, crude oil and oil-water mixture were over $151^{\circ}$, and even up to $173^{\circ}$. The wear life was 10 times as compared with PPS/PEEK coating, the brittleness and chemical reagent resistant of PPS/FEP/PEEK/PDMS coating was significantly better than PPS/PEEK coating.

Blend alloy is one of the most effective means to improving the properties of polymer due to large improvement has been achieved in the characteristics including thermal properties, mechanical properties, crystallizability and cost effectiveness by blending appropriate polymer materials [11-12]. In this article, the binary and ternary plastic composites of FEP, PEEK and poly(etherimide) (PEI) were fabricated by melt blending, the effects of crystal polymer PEEK and amorphous polymer PEI on the crystalline and thermal properties of crystal polymer FEP were investigated by FT-IR, SEM, DSC, XRD and TGA.

\section{Experimental materials and sample preparation}

The FEP, PEEK and PEI used in this work were obtained by Dupont, the glass-transition temperature $(\mathrm{Tg})$, melting point and thermal decomposition temperature $\left(\mathrm{T}_{d}\right)$ of FEP, PEEK and PEI were listed in Table 1 . The materials were preliminarily dried at $120^{\circ} \mathrm{C}$ for 5 hours, and then melt blended using a twin-screw extruder (model: SHJ-20, Nanjing Yajie Extrusion Equipment Co. Ltd., China). Extrusion processing parameters: temperatures of extruder sections for $230 \sim 365{ }^{\circ} \mathrm{C}$, screw speed 10 30 r/min, head pressure 9 11 MPa.

\subsection{Characterizations}

The chemical structures of the FEP/PEEK/ PEI composites were analyzed by Fourier Transform Infrared Spectroscopy (FTIR) (Nicolet IS-10). The spectra were recorded from 400 to $4000 \mathrm{~cm}-1$ with a resolution of $2 \mathrm{~cm}-1$ and 32 scans. The microstructural of FEP/PEEK/

Table 1. The thermodynamic parameters of FEP, PEEK and PEI

\begin{tabular}{|c|c|c|c|}
\hline Materials & $\mathrm{Tg},{ }^{\circ} \mathrm{C}$ & $\begin{array}{c}\text { Melting } \\
\text { point, }{ }^{\circ} \mathrm{C}\end{array}$ & $\mathrm{Td},{ }^{\circ} \mathrm{C}$ \\
\hline FEP & 30 & $265 \sim 285$ & 460 \\
\hline PEEK & 150 & 343 & 520 \\
\hline PEI & $215 \sim 217$ & 334 & 515 \\
\hline
\end{tabular}



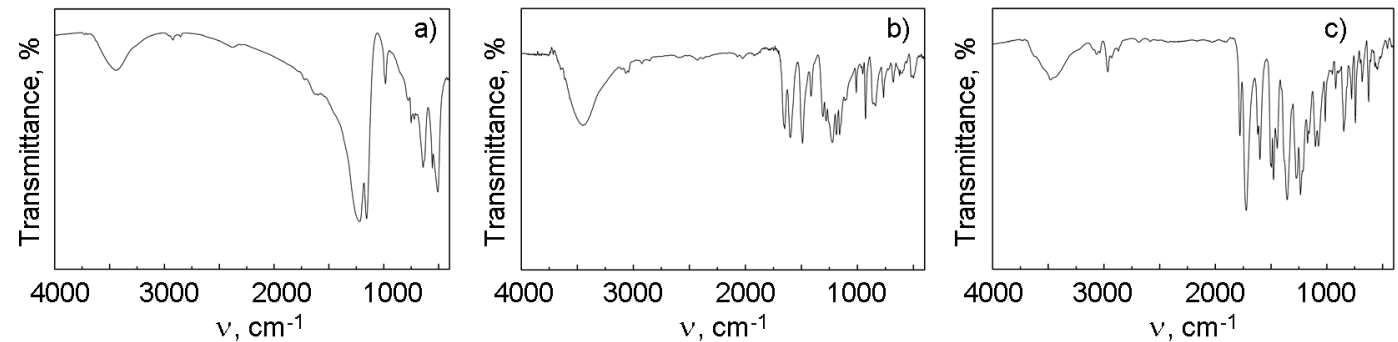

Fig. 1. FT-IR spectrum of pure FEP, PEEK and PEI (a: FEP; b: PEEK; c: PEI)
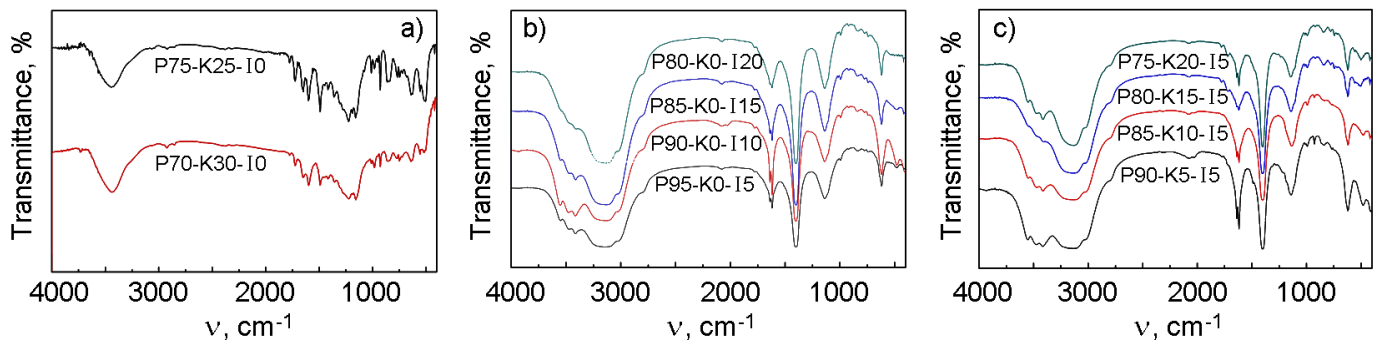

Fig. 2. FT-IR spectrum of FEP/PEEK, FEP/PEI and FEP/PEEK/PEI composites

PEI composites were observed by Scanning electron microscope (SEM) (HITACHI S-4800). The crystallization and thermal decomposition behaviors of FEP/PEEK/PEI composites were studied by X-ray diffraction (XRD) (DX-2700), differential scanning calorimetry (DSC) (TA Q2000) and thermal gravimetric analyzer (TGA) (TA Q-2000) with a nitrogen atmosphere, respectively. The testing temperature were $20 \sim 450{ }^{\circ} \mathrm{C}$ and $20 \sim 800{ }^{\circ} \mathrm{C}$ heated at $10{ }^{\circ} \mathrm{C} / \mathrm{min}$.

\section{Results and Discussion}

\subsection{Chemical Structure and Micro- structure of FEP based composites}

Figure 1 shows the FT-IR spectrum of pure FEP, PEEK and PEI plastics.The absorption peak observed at $1154 \mathrm{~cm}^{-1}$ was due to stretching vibrations of $\mathrm{C}-\mathrm{F}$ groups present in the spectrum of FEP. The peak appeared at 1654 $\mathrm{cm}^{-1}, 1597 \mathrm{~cm}^{-1}, 1220 \mathrm{~cm}^{-1}$ and $1014 \mathrm{~cm}^{-1}$ were belong to the stretching vibrations of $\mathrm{C}=\mathrm{O}$, benzene, $\varnothing-\mathrm{O}-\varnothing$ and $\mathrm{C}-\mathrm{O}$ groups present in the spectrum of PEEK. The peak appeared at 1776 $\mathrm{cm}^{-1}, 1597 \mathrm{~cm}^{-1}, 1355 \mathrm{~cm}^{-1}$ and $1014 \mathrm{~cm}^{-1}$ were belong to the stretching vibrations of $\mathrm{C}=\mathrm{O}$, benzene, $\mathrm{C}-\mathrm{N}$ and $\mathrm{C}-\mathrm{O}$ groups present in $\mathrm{PEI}$.

The FT-IT spectrum and characteristic absorption peak of the binary plastic composites of FEP/PEEK, FEP/PEI and FEP/PEEK/PEI ternary plastic composites were show in Figure 2 and Table 3. The characteristic peak of FEP/ PEEK composites appeared as linear superposition. With the content of PEEK increases, the characteristic peak position remain unchanged, while the peak area decreases slightly, as shown in Figure 2(a) and Table 3.
Table 2. Detailed formulae of FEP/PEEK/PEI composites

\begin{tabular}{|c|c|c|c|}
\hline Materials & FEP (phr) & $\begin{array}{c}\text { PEEK } \\
\text { (phr) }\end{array}$ & PEI (phr) \\
\hline P100-K0-I0 & 100 & 0 & 0 \\
\hline P0-K100-I0 & 0 & 100 & 0 \\
\hline P0-K0-I100 & 0 & 0 & 100 \\
\hline P85-K15-I0 & 85 & 15 & 0 \\
\hline P80-K20-I0 & 80 & 20 & 0 \\
\hline P75-K25-I0 & 75 & 25 & 0 \\
\hline P70-K30-I0 & 70 & 30 & 0 \\
\hline P95-K0-I5 & 95 & 0 & 5 \\
\hline P92-K0-I8 & 92 & 0 & 8 \\
\hline P90-K0-I10 & 90 & 0 & 10 \\
\hline P85-K0-I15 & 85 & 0 & 15 \\
\hline P80-K0-I20 & 80 & 0 & 20 \\
\hline P90-K5-I5 & 90 & 5 & 5 \\
\hline P85-K10-I5 & 85 & 10 & 5 \\
\hline P80-K15-I5 & 80 & 15 & 5 \\
\hline P75-K20-I5 & 75 & 20 & 5 \\
\hline
\end{tabular}

As shown in Figure 2(b) and Table 3, it was observed that the characteristic peak of FEP and PEI were appears at the spectrum of FEP/ PEI composites, entirely. However, the peak position of C-N present at PEI was shifted from 


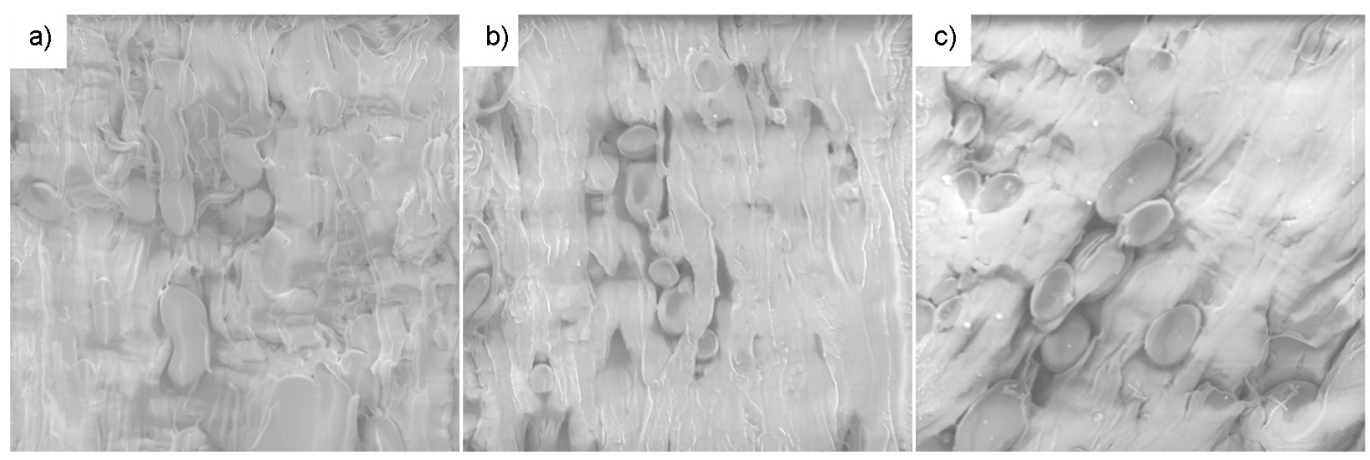

Fig. 3. SEM images of FEP/PEEK, FEP/PEI and FEP/PEEK/PEI composites (a: P70-K30-I0; b: P85-K0I15; c: P85-K10-I5)

Table 3. Characteristic absorption peak of the FEP based binary and ternary plastics composites

\begin{tabular}{|c|c|c|c|c|c|c|}
\hline Materials & $\mathrm{C}=\mathrm{O}$ & $\mathrm{C}-\mathrm{O}$ & $\mathrm{C}-\mathrm{F}$ & Ø-О-Ø & $\mathrm{C}=\mathrm{O}$ at imine ring & $\mathrm{C}-\mathrm{N}$ \\
\hline P100-K0-I0 & - & - & 1154 & - & - & - \\
\hline P0-K100-I0 & 1654 & 1014 & - & 1220 & - & - \\
\hline P0-K0-I100 & - & 1015 & - & - & 1776 & 1355 \\
\hline P70-K30-I0 & 1654 & 1014 & 1154 & 1220 & 一 & - \\
\hline P75-K25-I0 & 1654 & 1014 & 1154 & 1220 & 一 & - \\
\hline P95-K0-I5 & - & 1015 & 1154 & 一 & 1776 & 1360 \\
\hline P90-K0-I10 & - & 1015 & 1154 & 一 & 1776 & 1360 \\
\hline P85-K0-I15 & - & 1015 & 1154 & 一 & 1776 & 1360 \\
\hline P80-K0-I20 & - & 1015 & 1154 & - & 1776 & 1360 \\
\hline P90-K5-I5 & 1622 & 1015 & 1146 & 1220 & - & 1403 \\
\hline P85-K10-I5 & 1622 & 1015 & 1146 & 1220 & 一 & 1403 \\
\hline P80-K15-I5 & 1622 & 1015 & 1146 & 1220 & - & 1403 \\
\hline P75-K20-I35 & 1622 & 1015 & 1146 & 1220 & - & 1403 \\
\hline
\end{tabular}

$1355 \mathrm{~cm}^{-1}$ to $1360 \mathrm{~cm}^{-1}$ when PEI was added to FEP, the peak symmetry of FEP/PEI composites was changed from FEP to PEI as increasing the content of PEI. It indicated that there exists weak interaction between FEP and PEEK.

As compared with pure FEP, PEEK and PEI, the FT-IR spectrum of FEP/PEEK/PEI ternary composites was changed apparently, as shown in Figure 2(c) and Table 3. The stretching vibrations peak of $\mathrm{C}-\mathrm{F}$ was shifted from $1154 \mathrm{~cm}^{-1}$ to $1146 \mathrm{~cm}^{-1}$, and the peak symmetry was changed. The absorption peak of C-N was shifted from $1355 \mathrm{~cm}^{-1}$ to $1403 \mathrm{~cm}^{-1}$, while the peak position of $\mathrm{C}=\mathrm{O}$ was shifted from 1654 $\mathrm{cm}^{-1}$ to $1622 \mathrm{~cm}^{-1}$. From Figure 2(a) and Figure 2(b ), there almost have no interaction between the groups of FEP with PEEK and PEI, which can proved that the FT-IR spectrum changes of FEP/PEEK/PEI ternary composites was caused by the interaction of the polar groups presents at PEEK and PEI.

The SEM images of FEP based binary and ternary composites were shown in Figure 3. As shown in Figure 3(a), for FEP/PEEK binary composites, the filiform substance was considered as PEEK, which was dispersed in the matrix of FEP phase and there was a distinct interface between FEP and PEEK phase. For FEP/PEI composites, the PEI phase presented as particles was evenly distributed among the matrix of FEP phase and there was a distinct interface between FEP and PEI phase, as shown in Figure 3(b). In Figure 3(c), it can be observed that there was exists two-phase structure, many particles which was considered as PEEK and PEI mixed phase speculated by the formula content of FEP/PEEK/PEI ternary composites and FEP/PEEK/PEI FT-IR spectrum, the particles was uniformly dispersed in the matrix. In addition, there exists a dis- 

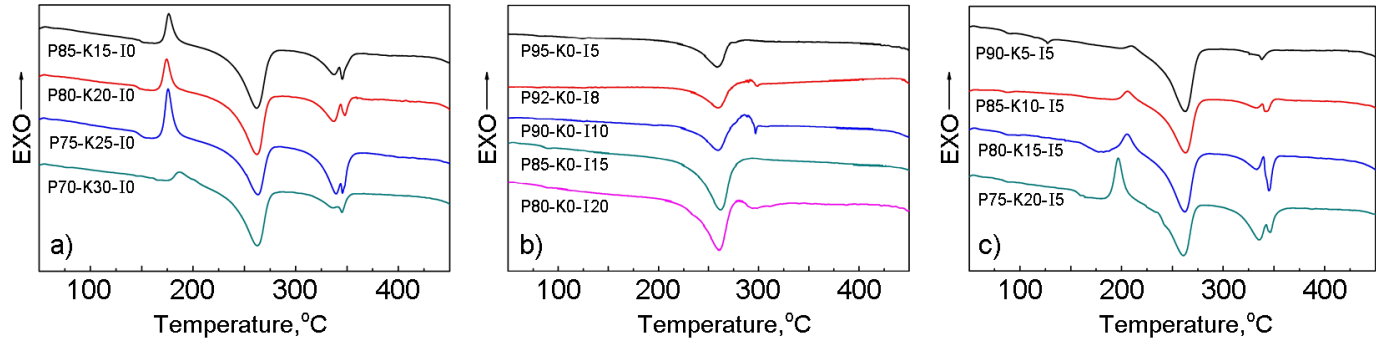

Fig. 4. DSC curves of FEP/PEEK, FEP/PEI and FEP/PEEK/PEI composites
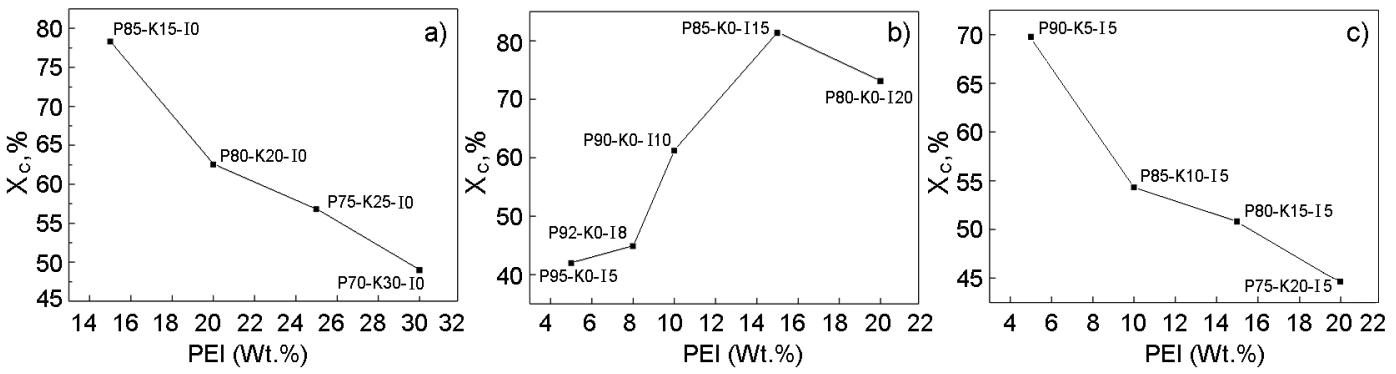

Fig. 5. Xc changing curves of FEP/PEEK, FEP/PEI and FEP/PEEK/PEI composites

tinct interface between particles and matrix in FEP/PEEK/PEI composites. From the SEM images of FEP based composites, it can indicated that FEP/PEEK, FEP/PEI and FEP/PEEK/PEI were not miscible in thermodynamics, because of the chemical inertness structure of FEP, and the PEEK and PEI were miscible in thermodynamics, which was consistent with the FT-IR spectrum.

\subsection{Crystallization and thermodynam-} ics behavior of FEP based composites

The DSC curves and DSC measurement data of FEP/PEEK, FEP/PEI and FEP/PEEK/ PEI composites were shown in Figure 4 and Table 4. The degree of crystallinity (Xc) of FEP/PEEK, FEP/PEI and FEP/PEEK/PEI composites were determined from the area of endothermic melting peaks were shown in Figure 5. As shown in Figure 4(a) and Table 4, the DSC curve of FEP/PEEK shows that the crystal-melting peak of FEP/PEEK composites and melting peak of FEP were increased with the content of PEEK increases. According to the DSC curves and SEM images, it can deduce that the $\mathrm{Tm}_{3}$ corresponds to PEEK and $\mathrm{Tm}_{2}$ corresponds to PEEK and FEP composites. The Xc curve of FEP/PEEK was shown in Figure $5(\mathrm{a})$, it can be seen that the Xc of FEP/PEEK composites decreased with the content of PEEK increases, the Xc of FEP/PEEK composites decreased was caused by the crystalline region were destroyed as PEEK added.

From the DSC curve and measurement data of FEP/PEI composites can be seen with the content of PEI increases, the crystal-melting peak
Table 4. DSC measurement data of FEP/ PEEK, FEP/PEI and FEP/PEEK/PEI composites

\begin{tabular}{|c|c|c|c|c|}
\hline Materials & $\mathrm{Tm}_{1}$ & $\mathrm{Tm}_{2}$ & $\mathrm{Tm}_{3}$ & $\mathrm{Tc}$ \\
\hline P70-K30-I0 & 262.90 & 345.50 & - & 185.90 \\
\hline P75-K25-I0 & 262.89 & 339.20 & 346.30 & 175.90 \\
\hline P80-K20-I0 & 262.64 & 337.80 & 347.80 & 174.60 \\
\hline P85-K15-I0 & 262.60 & 337.14 & 345.74 & 176.64 \\
\hline P95-K0-I5 & 259.30 & - & - & - \\
\hline P92-K0-I8 & 260.10 & - & - & - \\
\hline P90-K0-I10 & 260.44 & - & - & - \\
\hline P85-K0-I15 & 262.60 & - & - & - \\
\hline P80-K0-I20 & 261.40 & - & - & - \\
\hline P90-K5-I5 & 262.80 & 338.40 & - & 209.30 \\
\hline P85-K10-I5 & 263.60 & 332.19 & 342.79 & 206.49 \\
\hline P80-K15-I5 & 262.40 & 332.80 & 345.50 & 205.90 \\
\hline P75-K20-I5 & 261.44 & 335.84 & 346.24 & 196.84 \\
\hline
\end{tabular}

of FEP first increased and then decreased, and the $\mathrm{Xc}$ of $\mathrm{FEP} / \mathrm{PEI}$ composites were increases first and then decreases. When the content of PEI was under $15 \%$, the heterogeneous nucleating effect of PEI increases the nucleating and crystallizing rate, and then achieved improve- 
a)

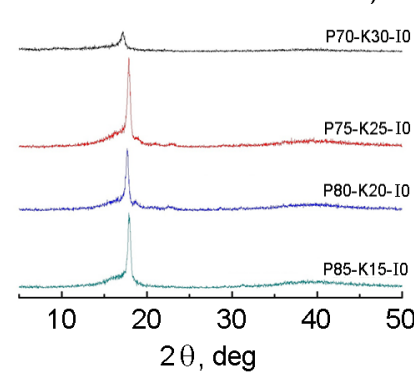

b)

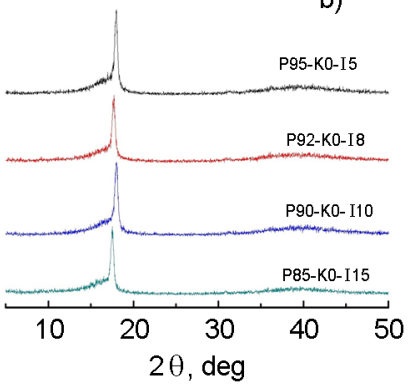

c)

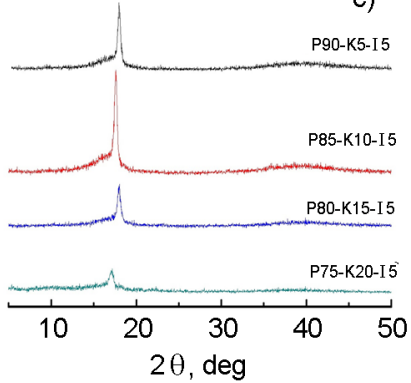

Fig. 6. XRD diffraction pattern of FEP/PEEK, FEP/PEI and FEP/PEEK/PEI composites

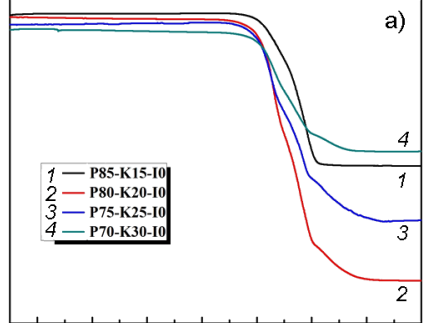

100200300400500600700800 Temperature, ${ }^{\circ} \mathrm{C}$

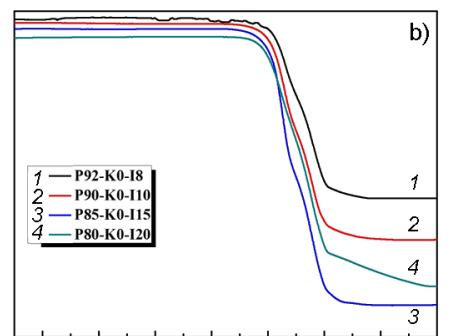

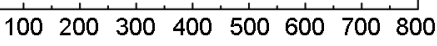
Temperature, ${ }^{\circ} \mathrm{C}$

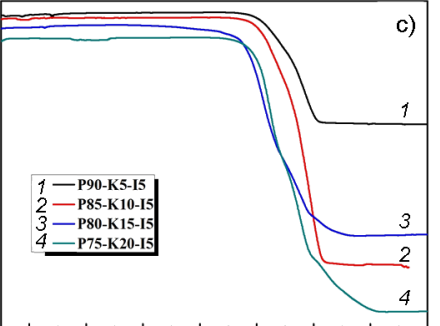

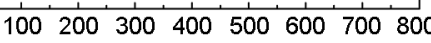
Temperature, ${ }^{\circ} \mathrm{C}$

Fig. 7. TGA curves of FEP/PEEK, FEP/PEI and FEP/PEEK/PEI composites

ment of the melt point and Xc of FEP. When the content of PEI was over $15 \%$, the crystalline region of FEP was destroyed, the Xc of FEP decreased, the melting peak decreases.

Figure 4(c) and Figure 5(c) shows the DSC and Xc curves of FEP/PEEK/PEI curves, the melt point of $\mathrm{Tm}_{1}, \mathrm{Tm}_{2}$ and $\mathrm{Tm}_{3}$ were corresponds to FEP, PEI and PEEK, respectively. It can be seen that the melt point of FEP were decreased, while the melt point of PEI and PEEK increased as the content of PEEK increases. The Xc of FEP was decreased with increases the content of PEEK, which was caused by the crystalline region were destroyed as PEEK content increases.

Figure 6 and Table 5 shows the XRD data of FEP/PEEK, FEP/PEI and FEP/PEEK/PEI composites. It can seen that the crystalline diffraction peaks of PEEK can not be discovered in Figure 6(a), with the content of PEEK increases, the half peak width of FEP were increases, which revealed that the grain size of FEP decreases with PEEK increases. For FEP/ PEI composites, when the content of PEI was under $15 \%$, the half peak width of FEP diffraction peak decreases with PEI content increases. For FEP/PEEK/PEI composites, the PEI concentration remain unchanged, with the PEEK content increases, the half peak width of FEP diffraction peak increases, which revealed that with PEEK increases, the grain size of FEP decreases.

Figure 7 and Table 6 shows the thermal stability of FEP based composites. It can be seen
Table 5. XRD measurement data of FEP/ PEEK, FEP/PEI and FEP/PEEK/PEI composites

\begin{tabular}{|c|c|c|}
\hline Materials & $29 /{ }^{\circ}$ & Half peak width \\
\hline P70-K30-I0 & 17.899 & 0.56 \\
\hline P75-K25-I0 & 17.680 & 0.46 \\
\hline P80-K20-I0 & 17.880 & 0.44 \\
\hline P85-K15-I0 & 17.162 & 0.41 \\
\hline P95-K0-I5 & 17.980 & 0.44 \\
\hline P92-K0-I8 & 17.702 & 0.41 \\
\hline P90-K0-I10 & 18.039 & 0.43 \\
\hline P85-K0-I15 & 17.519 & 0.41 \\
\hline P90-K5-I5 & 17.961 & 0.41 \\
\hline P85-K10-I5 & 17.619 & 0.43 \\
\hline P80-K15-I5 & 18.020 & 0.51 \\
\hline P75-K20-I5 & 17.158 & 0.66 \\
\hline
\end{tabular}

that the $\mathrm{T}_{\mathrm{i}}, \mathrm{T}_{\mathrm{m}}$ and $\mathrm{T}_{\mathrm{f}}$ of FEP/PEEK composites enhance with PEEK content increases when the PEEK content is under 25\%, and decreased when the PEEK content is over 25\%. For FEP/ PEI composites, the $\mathrm{T}_{\mathrm{i}}$ and $\mathrm{T}_{\mathrm{m}}$ decreased with PEI content increases, while the $\mathrm{T}_{\mathrm{f}}$ increases. For FEP/PEEK/PEI composites, the PEI content remain constant, when the content of PEEK increases, the $\mathrm{T}_{\mathrm{i}}, \mathrm{T}_{\mathrm{m}}$ and $\mathrm{T}_{\mathrm{f}}$ of FEP/ PEEK/PEI composites decreases. 
Table 6. TGA measurement data of FEP/ PEEK, FEP/PEI and FEP/PEEK/PEI composites

\begin{tabular}{|c|c|c|c||}
\hline Materials & $\begin{array}{c}\text { Initial } \\
\text { degrada- } \\
\text { tion tem- } \\
\text { perature } \\
\left(\mathrm{T}_{\mathrm{i}}\right)\end{array}$ & $\begin{array}{c}\text { maximum } \\
\text { mass loss } \\
\text { rate tem- } \\
\text { perature } \\
\left(\mathrm{T}_{\mathrm{m}}\right)\end{array}$ & $\begin{array}{c}\text { Finish } \\
\text { degrada- } \\
\text { tion tem- } \\
\text { perature } \\
\left(\mathrm{T}_{\mathrm{f}}\right)\end{array}$ \\
\hline P70-K30-I0 & 474.76 & 519.52 & 535.77 \\
\hline P75-K25-I0 & 484.12 & 530.98 & 551.51 \\
\hline P80-K20-I0 & 483.61 & 529.89 & 549.95 \\
\hline P85-K15-I0 & 471.87 & 529.71 & 549.84 \\
\hline P92-K0-I8 & 496.72 & 532.66 & 542.79 \\
\hline P90-K0-I10 & 438.35 & 532.72 & 546.94 \\
\hline P85-K0-I15 & 432.53 & 526.87 & 551.38 \\
\hline P80-K0-I20 & 450.05 & 520.95 & 551.88 \\
\hline P90-K5-I5 & 470.67 & 522.77 & 550.95 \\
\hline P85-K10-I5 & 467.18 & 524.27 & 549.15 \\
\hline P80-K15-I5 & 450.78 & 514.28 & 544.61 \\
\hline P75-K20-I5 & 438.45 & 526.09 & 547.50 \\
\hline
\end{tabular}

\section{Conclusion}

In this article, the FEP based binary and ternary plastic composites were fabricated by melting blend method. The structure, crystalline and thermal properties were investigated by FT-IR, SEM, DSC, XRD and TGA. The FEP/ PEEK, FEP/PEI and FEP/PEEK/PEI composites were presented thermodynamics incompatible according to the FT-IR, SEM and DSC analysis. The DSC measurement data shows that the Xc of FEP/PEEK decreases as PEEK content increases, the Xc of FEP/PEI enhance with PEI content increases when the PEI content under $15 \%$, and decreases when the PEI content over $15 \%$. For FEP/PEEK/PEI, the PEI content remain constant, with PEEK increases, the Xc of FEP/PEEK/PEI decreases. The XRD results shows that the grain size of FEP/PEEK decreases with PEEK increases, for FEP/PEI composites, when the content of PEI was under $15 \%$, the half peak width of FEP diffraction peak decreases with PEI content in- creases. For FEP/PEEK/PEI composites, with the PEEK content increases, the half peak width of FEP diffraction peak increases, which revealed that with PEEK increases, the grain size of FEP decreases. The TGA results shows that the $\mathrm{T}_{i}, \mathrm{~T}_{\mathrm{m}}$ and $\mathrm{T}_{\mathrm{f}}$ of FEP/PEEK composites enhance with PEEK content increases when the PEEK content is under $25 \%$, and decreased when the PEEK content is over $25 \%$, the $\mathrm{T}_{\mathrm{i}}$ and $\mathrm{T}_{\mathrm{m}}$ of FEP/PEI decreased with PEI content increases, while the $\mathrm{T}_{\mathrm{f}}$ increases. For FEP/PEEK/ PEI composites, the PEI content remain constant, when the content of PEEK increases, the $\mathrm{T}_{\mathrm{i}}, \mathrm{T}_{\mathrm{m}}$ and $\mathrm{T}_{\mathrm{f}}$ of FEP/PEEK/PEI composites decreases.

\section{Acknowledgements}

This work was financially supported by the Key Projects of the Outstanding Young Talents in Colleges and Universities of Anhui Province (gxyqZD2016373) and the Innovation Practice rojects of Chemistry and Materails(2014sjjd029).

\section{References}

1. Sahlin E, Beisler A T, Woltman S J, et al.. Anal. Chem., 74, 4566, 2011.

2. Bernett M K, Zisman W A., J.Phys.l Chem., 64, 1292,1960 .

3. Fujii H, Okumura T, Takahashi M, Electr. Eng. Japan, 188, 9, 2014.

4. Jiang Z, Guo Z, Jia Z, et al., e-Polymers, 2016, 16(2): 171-176.

5. Galante A M S, Galante O L, Campos L L., Nucl. Instr.Meth.Phys.Res., 619, 177, 2010.

6. Gupta B, Büchi F N, Scherer G G, J.Polymer Scie. Part A Polymer Chem., 90, 1931,2003.

7. Molinie P, Dessante P, Hanna R, et al. Dielectr. Electr.l Insul. IEEE Trans., 19,1215, 2012.

8. Liang J Z, Peng W., Polymer Test., 28, 386, 2009.

9. Zhao H, Zhang J, Ji T, et al., Tribology Lett., 45, 333, 2012.

10. Wang H, Liu Z, Zhu Y, et al. J.Polymer Res., 23, 1, 2016.

11. Paul D R and Barlow J W., J.Macromol, Scie.: Part C: Polymer Rev., 18, 109,1980.

12. Zhang R C, Xu Y, Lu Z Y, et al., J.Appl.Polymer Scie., , 1829, 2008. 